\title{
INTERNET MARKETING: SOLUSI BAGI PENGUSAHA BERMODAL KECIL
}

\author{
A. Cahyadi ${ }^{1}$
}

\begin{abstract}
Marketing is an integral part of any businesses who based its existence on profit. In its history marketing strategy has evolved several times into a strategy focusing more and more towards consumers needs. One of the marketing strategies that is currently being highlighted is Internet Marketing. This article tries to identify the advantage and weaknesses of Internet marketing and based on this fact recommends the most approriate internet promotion tools for e-enteprenuers with limited budget. At the end, article expresses some possibilities on Internet marketing adoption by Small and Medium Scale Enteprenuers in Indonesia.
\end{abstract}

Keywords: internet marketing, smale-scale, enterprenuer

ABSTRAK
Pemasaran merupakan bagian yang tidak terpisahkan dari sebuah bisnis yang
berorientasi laba, dalam sejarahnya strategi pemasaran telah mengalami beberapa
evolusi yang menjadikannya semakin terarah dan fokus pada keinginan konsumen, salah
satu metode pemasaran yang sedang trend saat ini ialah pemasaran lewat internet atau
lebih populer dengan sebutan Internet Marketing. Artikel mengupas keunggulan serta
kelemahan strategi bermula dari identifikasi kedua hal itu, merekomendasikan media
promosi internet yang tepat bagi seorang pengusaha bisnis online bermodal kecil.
Sebagai penutup, artikel memberikan pandangannya mengenai kemungkinan aplikasi
Internet-Marketing di Indonesia bagi Pengusaha Kecil-Menengah.
Kata kunci: internet marketing, bermodal kecil, pengusaha

${ }^{1}$ Staf pengajar Fakultas Ekonomi, UBiNus, Jakarta

Intemet Marketing: Solusi bagi Pengusaha Bermodal Kecil (A. Cahyadi) 


\section{PENDAHULUAN}

\section{Evolusi Strategi Pemasaran}

Sebuah bisnis yang menggantungkan eksistensinya pada jual-beli barang/jasa apapun jenisnya, perlu melakukan pemasaran. Namun, besar dan kecilnya usaha promosi itu tidak sama antarperusahaan, industri, bahkan antarpasar yang memiliki tingkat persaingan dan segmen konsumen yang berbeda-beda. Dalam perjalanan sejarahnya, strategi pemasaran telah mengalami banyak perubahan. Pada awal masa pertumbuhan industri, ditandai oleh revolusi industri yang melahirkan konsep mass production, pemasaran ditujukan untuk mendorong konsumen membeli produk-produk yang dihasilkan secara massal. Oleh karena itu, pada masa tersebut, pemasaran yang dikenal adalah pemasaran yang difokuskan pada masyarakat luas yang lebih populer dengan sebutan mass marketing.

Seiring dengan berjalannya waktu, posisi strategi mass marketing mengalami degradasi, ia sudah tidak lagi dianggap strategi yang paling tepat dalam memasarkan suatu produk atau jasa. Hal itu diakibatkan oleh meningkatnya jumlah produsen, merek, dan model barang serta jasa di pasar sehingga konsumen dihadapkan dengan pilihan/alternatif yang semakin banyak. Banyaknya alternatif produk bagi konsumen membuat konsumen cenderung memilih produk yang paling cocok untuk dirinya dan hal itu memaksa produsen untuk tidak hanya membuat satu produk untuk semua orang tetapi juga membuat produk sesuai kebutuhan segmen pasar tertentu. Paralel dengan hal itu, strategi promosi pun berubah dari promosi yang ditujukan untuk masyarakat luas (mass promotion) ke promosi yang ditujukan kepada segmen pasar tertentu atau individu tertentu (direct promotion).

Perkembangan strategi promosi tidak berhenti sampai disini. Dengan dikembangkannya teknologi dan jaringan internet, ikut bermunculan berbagai konsep bisnis baru, termasuk di dalamnya konsep e-commerce, yaitu jual beli barang atau jasa melalui internet. Konsep baru itu mengandalkan kesuksesannya dari pembelian barang atau jasa yang dilakukan oleh pengunjung internet sehingga lahirlah sebuah konsep berpromosi lewat media elektronik, khususnya internet yang disebut sebagai internet marketing atau interactive marketing.

Berbeda dengan mass marketing dan direct marketing yang biasanya bersifat pasif (pemberian informasi satu arah), sifat internet marketing ini adalah aktif atau dengan kata lain, Internet marketing memungkinkan konsumen berinteraksi dengan perusahaan pemasar melalui iklan. Contoh hal itu dapat terlihat dari iklan persegi panjang (banner) yang dipasang pada situs pencari yang terhubung (di-link) dengan situs penjual atau katalog penjual sehingga konsumen dapat langsung berinteraksi dengan penjual hanya dengan mengklik iklan tersebut. Lebih jauh, iklan di internet dapat disesuaikan dengan kebutuhan konsumen. Hal itu terlihat pada media, seperti keyword banner yang 
muncul berdasarkan kata pencari yang ditik pada kolom pencari. Secara lebih jelas, perbedaan antara ketiga strategi marketing itu terlihat pada Tabel 1 berikut.

Tabel 1 Perbandingan Antara Strategi Mass, Direct, dan Internet Marketing

\begin{tabular}{|c|c|c|c|c|}
\hline $\begin{array}{l}\text { Jenis } \\
\text { Strategi }\end{array}$ & Target Pasar & $\begin{array}{l}\text { Interaksi } \\
\text { Konsumen } \\
\text { dan Perusahaan } \\
\end{array}$ & Fleksibilitas & $\begin{array}{l}\text { Media yang } \\
\text { Sesuai }\end{array}$ \\
\hline $\begin{array}{l}\text { Mass } \\
\text { Marketing }\end{array}$ & Masyarakat luas & Pasif & $\begin{array}{l}\text { Sulit diubah dan } \\
\text { disesuaikan dengan } \\
\text { kebutuhan konsumen }\end{array}$ & $\begin{array}{l}\text { TV, Radio, } \\
\text { Surat Kabar, } \\
\text { Majalah }\end{array}$ \\
\hline $\begin{array}{l}\text { Direct } \\
\text { Marketing }\end{array}$ & $\begin{array}{l}\text { Kelompok } \\
\text { Konsumen } \\
\text { tertentu atau } \\
\text { individu }\end{array}$ & Pasif dan Interaktif & $\begin{array}{l}\text { Sulit dirubah dan } \\
\text { disesuaikan dengan } \\
\text { kebutuhan konsumen }\end{array}$ & $\begin{array}{l}\text { Brosur, } \\
\text { Katalog } \\
\text { kertas, } \\
\text { Pamflet }\end{array}$ \\
\hline $\begin{array}{l}\text { Internet } \\
\text { Marketing }\end{array}$ & $\begin{array}{l}\text { Kelompok } \\
\text { Konsumen } \\
\text { tertentu atau } \\
\text { individu }\end{array}$ & Interaktif & $\begin{array}{l}\text { Dapat disesuaikan } \\
\text { dengan kebutuhan } \\
\text { konsumen }\end{array}$ & $\begin{array}{l}\text { E-Mail, } \\
\text { Keyword } \\
\text { banner dan } \\
\text { Pop-up } \\
\text { window }\end{array}$ \\
\hline
\end{tabular}

\section{Manfaat dan Keunggulan Beriklan di Internet}

Walau usianya masih relatif muda, internet marketing mendapat sambutan yang cukup luas dari masyarakat bisnis, terutama di negara maju yang basis konsumen dan juga pengunjung internet cukup besar. Sambutan yang cukup luas itu tidak terlepas dari manfaat dan keunggulan yang dapat diperoleh dari beriklan di internet. Secara lebih detail, keunggulan dan manfaat itu dapat dilihat pada Tabel 2.

Tabel 2 Keunggulan Beriklan di Internet

\begin{tabular}{ll}
\hline Keunggulan atau Manfaat & Penjelasan \\
\hline Cakupan Global & $\begin{array}{l}\text { Internet merupakan jaringan komputer global yang dapat } \\
\text { diakses dari belahan bumi manapun dan hal ini } \\
\text { menjadikannya sebagai media promosi yang bersifat global }\end{array}$ \\
Biaya yang relatif Lebih Murah & $\begin{array}{l}\text { Berpromosi di Internet relatif lebih murah dibandingkan } \\
\text { dengan memakai media elektronik lainya dengan jangkauan }\end{array}$ \\
& yang sama \\
Relatif lebih mudah diupdate & Iklan di Internet dapat lebih mudah diupdate tidak seperti \\
& iklan di media cetak yang tidak dapat ditarik kembali \\
& setelah diterbitkan tanpa merugikan pihak penerbit. \\
Dapat dihubungkan dengan proses & Iklan di Internet juga dapat dihubungkan dengan situs \\
transaksi & penjual dan bahkan katalog sehingga pengunjung yang \\
& tertarik dengan iklan tersebut dapat langsung mengkliknya \\
untuk memulai suatu proses transaksi dengan penjualnya.
\end{tabular}


Tabel 2 Keunggulan Beriklan di Internet (lanjutan)

\begin{tabular}{ll}
\hline Memiliki konten Multimedia & $\begin{array}{l}\text { Iklan di internet juga dianggap lebih efektif dalam hal } \\
\text { visualisasi produk atau jasa berkat kemampuannya dalam } \\
\text { menampilkan teks, gambar, video dan suara sekaligus. }\end{array}$ \\
$\begin{array}{l}\text { Dapat disesuaikan dengan } \\
\text { kebutuhan konsumen }\end{array}$ & $\begin{array}{l}\text { Iklan di internet juga dapat disesuaikan dengan permintaan } \\
\text { (customizable) }\end{array}$ \\
& $\begin{array}{l}\text { memumen seperti contohnya keyword banner yang akan } \\
\text { diketikan pada kolom pencari }\end{array}$ \\
\hline
\end{tabular}

Pertanyaan selanjutnya setelah melihat keunggulan-keunggulan Internet marketing yang dijabarkan diatas adalah alat promosi apa saja yang tersedia bagi seorang pengusaha di Internet dan apa saja karakteristik dari alat-alat promosi tersebut ?

\section{Jenis Promosi di Internet}

Banyak sekali jenis promosi yang tersedia di internet namun untuk menyederhanakannya, dalam artikel ini digunakan delapan kategori utama yang diusulkan oleh Dr. Ralph F Wilson seorang e-commerce consultant. Dalam artikelnya yang berjudul "The Eight Essential Types of Internet Promotion", Dr. Wilson mengategorikan jenis promosi di internet sebagai berikut.

1. Search Engines: Situs pencari yang menawarkan fasilitas pencarian situs maupun produk yang ditawarkan di internet. Situs itu dapat dimanfaatkan dengan mendaftarkan alamat situs (URL address) di situs pencari, seperti Google.com dan sebagainya. Tinggi atau rendahnya peringkat tergantung dari konsistensi situs dan popularitas situs tersebut.

2. URL Linking: Suatu metode promosi dengan membuat link (hubungan) dengan situs lain atau dengan mendaftarkan alamat URL (alamat situs) ke situs direktori, seperti yahoo.com dan msn.com.

3. Viral Promotion, yaitu metode promosi dengan meniru promosi dari mulut ke mulut, hanya saja di internet, promosi itu dilakukan dengan menempelkan iklan teks yang sering juga berisi link ke situs/katalog pada setiap e-mail yang Anda kirim ke pelanggan atau rekanan, bahkan ada juga yang menempelkannya pada software atau artikel atau publikasi lain yang dapat di-download secara gratis dari situs Anda.

4. Public Relations: Suatu cara memperkenalkan situs atau produk dengan cepat dan menarik sebanyak mungkin pengunjung atau pembeli adalah dengan mengumumkannya di berbagai publikasi online menggunakan jasa News Release Service yang ada di internet.

5. E-Mail Publishing: Suatu metode berpromosi dengan e-mail dan pengusaha mengirim e-mail kepada calon pembeli potensial dan membujuk mereka untuk datang ke situsnya dan membeli produk yang ditawarkan. Promosi dengan e-mail itu biasanya dimulai dengan meminta pelanggan atau pengunjung mendaftarkan diri pada free newsletter atau discussion group untuk memperoleh alamat $e$-mail-nya. 
6. Networking: Suatu metode promosi di internet dengan memanfaatkan hubungan yang dibina dengan calon pelanggan dan rekanan dan cara itu dapat ditempuh melalui pembuatan dan pengembangan mailing list atau discussion group.

7. Paid Advertising: Kebanyakan dari metode tersebut dapat dilakukan dengan biaya yang relatif murah namun efektivitasnya pun relatif terbatas. Bila metode tersebut tidak memadai untuk menarik jumlah pengunjung yang signifikan, seorang pengusaha dapat menggunakan alat promosi yang bersifat komersial, antara lain sebagai berikut.

a. Iklan Banner yang dipajang pada halaman situs populer dengan tarif berdasarkan hitungan CPM (Cost Per Thousands Impressions) atau biaya per seribu tayang. Biasanya tarifnya berkisar sekitar USD 1 s.d. 10 untuk konsumen umum dan USD. 35 s.d. 50 untuk segmen konsumen tertentu.

b. Listing pada situs portal terkemuka, seperti MSN atau Lycos. Untuk hal itu, tarifnya dapat bersifat flat maupun persentase.

c. Iklan pada e-Mail Newsletter. Iklan pada e-mail newsletter itu dipasang pada setiap e-mail newsletter yang dikirim kepada para langganan suatu newsletter. Tarif beriklan di media ini relatif terjangkau.

\section{PEMBAHASAN}

\section{Faktor Pembatas Efektivitas Beriklan di Internet}

Keunggulan dan keragaman metode promosi di internet tidak secara otomatis menjadikan metode itu sebagai metode terbaik. Bagi seorang pebisnis online, banyak faktor yang membatasi efektivitas beriklan di internet ,antara lain sebagai berikut.

1. Kejenuhan pengunjung dalam melihat Iklan. Banyaknya promosi yang dilakukan oleh pengiklan, baik melalui banner, e-mail, pop-up windows, dan sebagainya, membuat konsumen dan pengunjung internet jenuh.

2. eterbatasan Waktu. Banyak pengunjung internet yang mengakses internet dari tempat kerja umumnya memiliki keterbatasan waktu sehingga tidak dapat terlalu lama melihat dan berinteraksi dengan iklan.

3. Keterbatasan Biaya. Kebanyakan pengunjung dari negara berkembang mengakses internet melalui dial-up dan mereka dikenakan tarif akses per jam sehingga hal itu turut membatasi waktu pemakaian internet.

4. Perhitungan Biaya Iklan yang cenderung memihak. Kebanyakan tarif beriklan berdasar pada CPM (Cost Per Thousands Impression) atau biaya per seribu tayang, hal itu dirasakan kurang adil mengingat tidak semua orang yang melihat iklan mengklik iklan tersebut. Menurut Dr. Wilson dalam tulisannya yang berjudul "How to Advertise Your Site on a Slim Budget", hanya $-2 \%$ orang yang terekspos dengan suatu iklan benar-benar mengklik iklan 
tersebut dan dari $1-2 \%$ tersebut hanya $0.5-5 \%$ saja yang benar-benar membeli barang atau jasa yang ditawarkan.

\section{Memilih Jenis Promosi yang Tepat bagi Pengusaha Menengah dan Kecil}

Hal tersebut memaksa seorang pengusaha untuk benar-benar mempertimbangkan metode dan alat promosi mana yang tepat untuk bisnisnya. Hal itu terlihat dari dua sisi, yaitu sisi efektivitas dan biaya.

\section{Memilih Metode dan Media Promosi Dilihat dari Sisi Efektivitas}

Dari sisi efektivitas metode atau alat promosi yang ideal bagi seorang pengusaha adalah metode yang menawarkan jangkauan (reach) yang paling luas, memiliki frekuensi (frequency) tayang paling tinggi, dan pengaruh (impact) terhadap konsumen yang paling besar (lihat grafik pada Gambar 1).

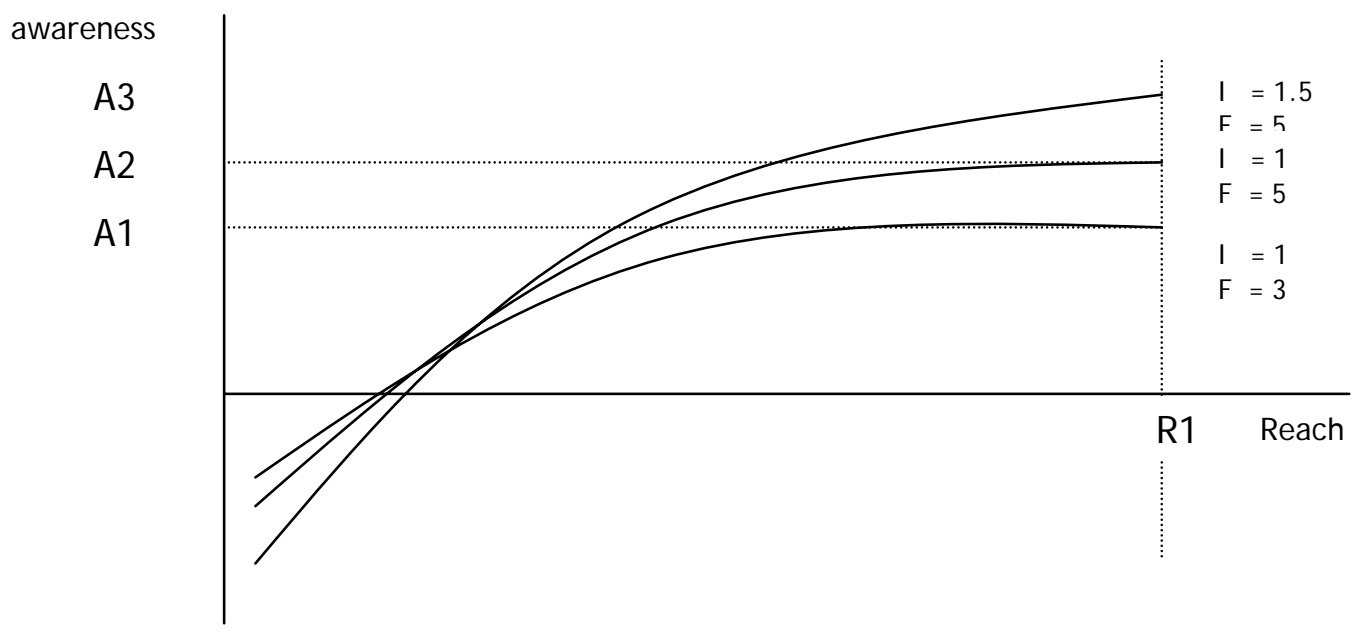

Gambar 1 Grafik Peran Frequency, Impact, dan Reach suatu Media Promosi dalam Membangun Kesadaran Konsumen

Grafik tersebut memperlihatkan bahwa dengan tingkat jangkauan yang sama, sebuah medium promosi dapat meningkatkan kesadaran masyarakat akan suatu merek dengan meningkatkan frekuensi tayang iklannya. Kesadaran masyarakat akan merek juga dapat ditingkatkan dengan meningkatkan pengaruh atau impact media tersebut dengan jalan beralih ke media yang lebih banyak dibaca atau dilihat orang konsumen target. Sebagai contoh, mengalihkan iklan makanan bayi dari majalah wanita ke majalah keluarga akan meningkatkan impact iklan tersebut. 
Berdasarkan Pengaruh, Frekuensi, dan Jangkauan suatu iklan, seorang pengusaha perlu mempertimbangkan berbagai faktor dalam memilih media berpromosi yang tepat baginya. Faktor itu sebagai berikut.

1. Karakteristik Produk: Sifat dan karakteristik produk ikut menentukan media promosi yang tepat baginya untuk contoh produk yang perlu didemokan. Seperti kendaraan bermotor, barang elektronik, dan sebagainya, lebih tepat bila diiklankan di media yang mampu menampilkan gambar bergerak, seperti TV dan internet sedangkan produk yang perlu diperlihatkan desain dan warnanya, seperti pakaian jadi cocok untuk ditampilkan di majalah berwarna atau gambar statis berwarna di internet.

2. Karakteristik Konsumen Target: Sifat dan kebiasaan konsumen juga menjadi penentu bagi pemilihan media promosi yang tepat, contohnya produk buat remaja cocok ditampilkan di majalah remaja atau situs remaja sedang produk bagi para eksekutif cocok ditampilkan pada majalah bisnis atau situs bisnis.

3. Karakteristik informasi yang ditampilkan: Sifat informasi yang ditampilkan juga menentukan pemilihan media promosi yang tepat, contohnya bila iklan ditujukan untuk mempromosikan suatu program diskon dan potongan harga yang berlaku dalam waktu dekat (keesokan harinya misalnya) maka media yang paling tepat adalah media yang terbit atau muncul setiap hari, misalnya surat-kabar, radio, dan televisi atau $e$ mail dan newsletter untuk media internet.

\section{Memilih Metode dan Media Promosi dari Segi Biaya}

Dari segi biaya, Dr. Ralph Wilson menganjurkan agar pengusaha kecil dan menengah mempertimbangkan beberapa media berbiaya rendah, seperti berikut ini.

\section{Low Cost Public Relations}

Menurut Wilson, ada beberapa cara yang relatif murah untuk mengirim berita iklan (berita yang berisi informasi positif mengenai berdirinya suatu situs munculnya suatu produk baru atau adanya suatu program diskon, undian berhadiah, dan sebagainya) dan memuatnya pada berbagai media online maupun offline. Beberapa perusahaan menerima jasa memuat berita iklan, antara lain sebagai berikut.

a. PR Newswire (http://www.prnewswire.com) dan Business Wire (http://wwwbusinesswire.com/aboutbw/) keduanya menangani media tradisional maupun online.

b. Internet News Bureau (http://www.newsbureau.com/welcome.cgi?1017) menetapkan tarif sebesar USD 225 untuk setiap penerbitan dan bahkan menyediakan jasa penulisan berita iklan dengan biaya tambahan.

c. Eric Wards NetPOST (http://www.netpost.com) menawarkan jasa pengiriman berita iklan ke para jurnalis yang memintanya. 


\section{Low Cost Banner Ads}

Untuk pemasangan banner yang murah, Dr. Wilson menyarankan untuk mencoba jasa pemasangan banner yang dikelola oleh Link Exchange (http://www.linkexchange.com) . Linkexchange menawarkan kepada pemasang iklan 2 pilihan berikut.

a. Iklan yang tidak ditargetkan (Untargeted Ads) yang muncul secara random pada 250.000 situs jaringan afiliasi Link Exchange. Iklan itu memakan biaya USD 8 10 per seribu tayang.

b. Iklan yang setengah diarahkan (Semi Targeted Ads), yaitu iklan yang ditempatkan pada 22 kategori puncak, seperti arts and humanities, autos boats and planes, business, computer and internet, culture and religion, education and reference, entertainment and leisure, games, health and fitness, hobbies and interest, life family issues, money and finance, movies and television, music and radio, nonprofit and resource organization, personal homepages, pets home and garden, science and technology, shopping and services, society and issues dan sports and travel. Biaya iklan jenis ini berkisar antara USD 14 - USD 16 per seribu tayang.

\section{Newsletter Ads}

Banyak pengusaha online yang menemukan bahwa tarif beriklan yang paling ekonomis diperoleh dari beriklan di Newsletter, yaitu dari iklan yang ditempelkan pada $e$ mail berita (newsletter). Banyak Newsletter menentukan tarif iklan secara berbeda-beda ada yang memakai tarif tunggal (flat rate) ada juga yang menggunakan sistem CPM (tarif per seribu tayang).

\section{Keyword Purchases}

Kata kunci adalah suatu alat promosi yang penting di internet karena setiap kali seorang pengunjung internet mencari situs atau produk di internet, ia selalu mengetikkan kata kunci yang berkaitan dengan situs atau produk tersebut. Pada beberapa situs pencari populer, kata kunci itu dapat dibeli. Beriklan dengan cara itu biasanya dikenakan biaya berdasar sistem CPM (tarif per seribu tayang) dan berhubung sifatnya yang lebih terfokus, dengan kata lain iklan ditayangkan hanya bila ada pengunjung yang mengetikkan kata kunci yang sesuai dengan iklan maka cara itu lebih mahal ketimbang iklan yang ditujukan untuk umum. Namun, bila dihitung efektivitasnya dalam menjaring pengunjung, iklan itu masih relatif murah.

\section{Pay per Click or Pay per Action}

Beberapa situs menentukan biaya beriklan berdasarkan klik atau lebih dikenal dengan istilah pay per click add. Hal itu dianggap lebih adil berdasarkan rasio bahwa pengunjung yang mengklik iklan lebih mungkin membeli dari pengunjung yang hanya 
sekedar melihat. Salah satu perusahaan yang menawarkan pemasangan iklan berdasarkan tarif per klik adalah Value Click (http://www.valueclick.com). Selain metode pay per click, ada juga situs yang menagih biaya iklan hanya bila pengunjung mengisi formulir berlangganan atau formulir pemesanan dan metode itu disebut pay per action method yang lebih memihak kepada pemasang iklan. Irv Brechner dari Transact Network (http://smartbiz.com/sbs/transact.htm) menawarkan jasa jenis itu.

\section{Search Engine Positioning}

Pendekatan pemasaran yang tidak kalah pentingnya adalah dengan mendesain situs sedemikian rupa sehingga posisinya dalam sebuah situs pencari menempati urutan atas. Hal itu dapat dilakukan dengan berbagai cara, antara lain sebagai berikut.

a. Memastikan bahwa kata kunci yang relevan dengan bisnis tertera dalam halaman situs, terutama pada bagian header-nya (pada bagian tag keywords).

b. Memastikan informasi pada situs relevan dengan bidang usaha.

c. Memastikan bahwa situs memiliki link dengan situs lain yang relevan dengan usaha.

Mendesain ulang situs untuk berkompetisi dengan situs lain yang bermunculan sangatlah merepotkan dan memakan biaya dan waktu yang cukup banyak. Oleh sebab itu, seorang pengusaha dianjurkan untuk mensubkontrakkan pekerjaaan itu ke pihak ketiga.

\section{Kasus Indonesia}

Pertanyaan yang muncul dari menyimak hal tersebut adalah bagaimana dengan pengusaha kecil dan menengah di Indonesia, dapatkah mereka turut memanfaatkan media promosi tersebut untuk kepentingan bisnisnya. Jawaban pertanyaan itu tergantung dari target pasar pengusaha tersebut. Bila target pasarnya adalah pasar domestik maka tentu saja media promosi internet saja masih jauh dari cukup. Hal itu disebabkan masih kurangnya basis konsumen internet di Indonesia yang diperlihatkan oleh rendahnya nilai berbagai indikator, seperti tingkat kepemilikan PC, Persentase Penduduk yang telah terhubung dengan internet, serta tingkat kepemilikan sambungan telepon relatif dibandingkan dengan beberapa negara Asia (lihat Tabel 3).

Tabel 3 Perbandingan Tingkat Kepemilikan PC, Sambungan Internet, dan Sambungan Telepon di Beberapa Negara Asia

\begin{tabular}{lllll}
\hline & PC/100 penduduk & \% Populasi yang Online & $\begin{array}{l}\text { Sambungan Telepon/100 } \\
\text { penduduk }\end{array}$ \\
\hline Indonesia & 0.99 & 1.2 & 3.14 \\
Filipina & 1.99 & 3 & 3.92 \\
Brunei & 6.22 & 1.2 & 24.59 \\
Cina & 1.59 & 2.1 & 11.12 & \\
\hline Sumber: & UN & DPEPA & (Division for Public Economic and Public Administration)
\end{tabular}




\section{PENUTUP}

\section{Simpulan}

Dengan terbatasnya keefektifan media promosi internet, peran media tradisional menjadi lebih besar dalam menarik pembeli dan mendongkrak penjualan. Peran media promosi internet menjadi lebih penting bila pasar target pengusaha UKM menyangkut juga pasar manca negara. Namun, suatu hal yang perlu diwaspadai bila ingin memasarkan produk yang belum memiliki nama besar di pasar luar negeri ialah resiko rendahnya minat pembeli tanpa adanya suatu jaminan atau dukungan pemasaran dari perusahaan iklan, importir, serta distributor di negara pengimpor sehingga peran mitra asing dalam memasarkan produk secara online sekalipun masih belum dapat dikesampingkan.

\section{DAFTAR PUSTAKA}

Kotler, Philip. 2003. Marketing Management. Upper Saddle River, New Jersey: Prentice Hall.

Strauss, Judy and Raymond Frost. 2001. E-Marketing. Upper Saddle River, New Jersey: Prentice Hall.

Turban, Efraim, et al. 2002. Electronic Commerce a Managerial Perspective. Upper Saddle River, New Jersey: Prentice Hall.

Wilson, Ralph F. 2000. “The Eight Essential Types of Internet Promotion,” diakses 13 April 2004 dari http://wilsonweb.com/articles/checklist.html

Wilson, Ralph F. 1998. “How to Advertise Your Site on a Slim Budget,” diakses 13 April 2004 dari http://wilsonweb.com/articles/checklist.html 